\title{
Perbandingan Dua Model Pertumbuhan dalam Analisis Pertumbuhan Itik Magelang di Balai Pembibitan dan Budidaya Ternak Non Ruminansia Banyubiru, Kabupaten Semarang
}

\author{
Comparison of Two Growth Models in Growth Analysis of Magelang Duck at Balai \\ Pembibitan dan Budidaya Ternak Non Ruminansia Banyubiru, Kabupaten Semarang
}

\author{
W. P. Prayogo, E. Suprijatna, dan E. Kurnianto* \\ Fakultas Peternakan dan Pertanian, Universitas Diponegoro, \\ Kampus Tembalang, Semarang 50275 \\ Email : wahyu.priyo.prayogo@gmail.com \\ *Email Korespondensi: kurniantoedy17@gmail.com
}

\begin{abstract}
The objective of this study was to determine the growth curve models of Magelang ducks of second generation using two growth models. The data used were the body weight of Magelang duck from 0 to 8 weeks old taken in every three days. Ducks used were 297 birds, consisted of 113 males and 184 females. Data were analyzed by using two models, those were Gompertz and Logistic. The results showed that the growth curve models had different levels of accuracy. Regression models equation of Gompertz at male was $\mathrm{Y}=2386.88 \exp \left(-3.89 \exp ^{-}\right.$ $\left.{ }^{0.03}\right)$ and female was $\mathrm{Y}=1760.02 \exp \left(-3.78 \exp ^{-0.05}\right)$, whereas Logistic models at male was $\mathrm{Y}=1558.17 /(1+$ $\left.19.78 \exp ^{-0.08}\right)$ and females $\mathrm{Y}=1229.90 /\left(1+18.44 \exp ^{-0.08}\right)$. Inflection point of Magelang duck Gompertz model was at $\mathrm{Yi}=878.08 \mathrm{~g}$ and $\mathrm{ti}=42.44$ days, while female ducks was $\mathrm{Yi}=647.48 \mathrm{~g}$ and ti=37.98 days. Inflection point of model Logistic for male ducks Magelang was Yi=779.09 $\mathrm{g}$ occurs in ti $=39.27$ days and female for was $\mathrm{Yi}=624.45 \mathrm{~g}$ and $\mathrm{ti}=36.43$ days. in conclusion, two growth models used for fitting growth in Magelang duck had a high degre of accuracy in which Gompertz model alowed the higher accuracy level compared to Logistic Model.
\end{abstract}

Key words: Magelang Ducks, equation model of the growth curve, the inflection point

\begin{abstract}
ABSTRAK
Penelitian ini bertujuan untuk menganalisis model kurva pertumbuhan pada itik Magelang generasi ke-2 dengan menggunakan dua model pertumbuhan yang berbeda. Data yang digunakan adalah pertumbuhan bobot badan hasil penimbangan itik Magelang dari umur 0 sampai 8 minggu yang diambil setiap 3 hari sekali. Itik yang digunakan sebanyak 297 ekor yang terdiri dari 113 ekor itik jantan dan 184 ekor itik betina. Data dianalisis dengan menggunakan model yaitu Gompertz dan Logistic untuk menggambarkan pola pertumbuhan setiap jenis kelamin. Hasil yang diperoleh menunjukkan model kurva pertumbuhan memiliki tingkat akurasi yang berbeda. Persamaan regresi model Gompertz pada itik jantan $\mathrm{Y}=2.386,88 \exp \left(-3,89 \exp ^{-0,03}\right)$ dan betina $\mathrm{Y}=1.760,02 \exp$ $\left(-3,78 \exp ^{-0,05}\right)$, sedangkan model Logistic pada itik jantan $\mathrm{Y}=1.558,17 /\left(1+19,78 \exp ^{-0,08}\right)$ dan betina $\mathrm{Y}=$ $1.248,90 /\left(1+18,44 \exp ^{-0,08}\right)$. Titik infleksi itik Magelang jantan dicapai pada $\mathrm{Y}_{\mathrm{i}}=878,08 \mathrm{~g}$ dan $\mathrm{t}_{\mathrm{i}}=42,44$ hari, itik betina dicapai $\mathrm{Y}_{\mathrm{i}}=647,48 \mathrm{~g}$ dan $\mathrm{t}_{\mathrm{i}}=37,98$ hari, sedangkan titik infleksi pada model Logistic itik Magelang jantan dicapai $\mathrm{Y}_{\mathrm{i}}=779,09 \mathrm{~g}$ terjadi di $\mathrm{t}_{\mathrm{i}}=39,27$ hari dan itik betina dicapai di $\mathrm{Y}_{\mathrm{i}}=624,45 \mathrm{~g}$ dan $\mathrm{t}_{\mathrm{i}}=36,43$ hari. Simpulan penelitian ini adalah kedua model memiliki tingkat akurasi yang tinggi, Model Gompertz memiliki tingkat akurasi yang lebih tinggi dibandingkan dengan Logistic.
\end{abstract}

Kata kunci: Itik Magelang, persamaan model kurva pertumbuhan, titik infleksi

\section{PENDAHULUAN}

Itik Magelang merupakan plasma nutfah asli dari Indonesia yang berasal dari daerah Magelang. Itik Magelang ini sering disebut itik kalung oleh warga setempat sebab memiliki keunikan yaitu memiliki warna bulu putih melingkar di bagian leher (Yuniwarti dan Muliani, 2014). Itik Magelang dapat memproduksi telur yang tinggi hingga mencapai 250-300 
butir per ekor per tahun, namun kenyataannya untuk mendapatkan 150 butir per ekor per tahun masih sulit (Mahfudz et al., 2005). Hal ini akibat dari sistem perkawinan yang dilakukan oleh peternak masih secara alami, tidak adanya seleksi calon induk-pejantan unggul dan belum adanya program pembibitan (breeding) yang baik. Oleh karena itu penelitian pertumbuhan itik magelang sangat diperlukan untuk memperoleh data dasar pertumbuhan itik magelang dalam melakukan pembibitan itik Magelang.

Pertumbuhan adalah salah satu faktor penting untuk mengetahui perkembangan bobot badan. Pertumbuhan ini merupakan proses pertambahan sel yang tidak dapat kembali ke semula (irreversible) dan merupakan sifat kuantitatif karena dapat diketahui melalui pertambahan bobot badan. Penelitian pertumbuhan dilakukan untuk mengetahui pertumbuhan itik Magelang yang akan diseleksi sebagai bibit. Pertumbuhan yang baik dapat diketahui dalam waktu yang lama untuk mengetahui bobot-bobot dewasa, sehingga akan memerlukan banyak waktu dan biaya.

Penelitian pertumbuhan dapat dilakukan selama dua bulan dengan menggunakan banyak model pertumbuhan. Menurut Salman et al. (2015) model yang dapat digunakan dalam parameter pertumbuhan adalah Von bertalanffy, Richards, gompertz dan logistic. Model Logistic, Gompertz dan Asymptotic digunakan Kurnianto et al. (1997) pada penelitian tikus. Brahmantyo dan Raharjo (2011) menggunakan model Gompertz dalam menduga pertumbuhan kelinci.
Model-model pertumbuhan tersebut memiliki persamaan dan tingkat akurasi dalam menduga bobot badan yang berbeda. Oleh karena itu akan dilakukan analisis pertumbuhan pada itik Magelang dengan menggunakan perbandingan dua model pertumbuhan. Model Gompertz dengan Logistik yang akan digunakan untuk mendapatkan model kurva pertumbuhan dan bobot dewasa yang terbaik. Penelitian ini bertujuan untuk mengetahui model kurva pertumbuhan itik Magelang mulai umur 0 sampai 8 minggu dan mencari bobot dewasa untuk dijadikan induk. Manfaat dari penelitian ini adalah memperoleh informasi pertumbuhan dan menggambarkan pola pertumbuhan selama 8 minggu serta mendapatkan bobot dewasa itik Magelang untuk dijadikan induk.

\section{MATERI DAN METODE}

Penelitian yang berjudul Analisis Pertumbuhan Itik Magelang telah dilaksanakan pada bulan Oktober 2015 hingga bulan Februari 2016 di Satuan Kerja (SATKER) Itik Banyubiru, Kabupaten Semarang.

Materi yang digunakan dalam penelitian ini adalah Itik Magelang generasi ke-2 (G2) yang diperoleh dari perkawinan itik Magelang generasi pertama (G1). Alat yang digunakan dalam penelitian adalah keranjang (box) untuk tempat telur yang akan masuk ke dalam mesin hatcher dan memindahkan itik yang baru menetas ke kandang Day Old Duck 
(DOD), kabel pengait untuk menandai kaki itik, tempat pakan dan minum, timbangan untuk menimbang bobot badan itik, kandang flock induk dan DOD, lampu sebagai penerangan dan juga penghangat DOD (G2) dan alat tulis untuk mencatat hasil data penelitian.

Penelitian dilaksanakan dalam tiga tahapan, yaitu (1) Persiapan kandang liter 9 flok, kabel pengait, alat tulis, tempat pakan dan minum, serta lampu. (2) Pelaksanaan yaitu dengan mengambil data hasil timbangan itik magelang setiap 3 hari sekali selama 2 bulan dan 15 kali penetasan. (3) Analisis data. Data yang digunakan dalam penelitian ini adalah data bobot badan itik Magelang jantan dan betina G2, yang merupakan hasil dari penimbangan itik jantan 113 ekor dan betina 184 ekor yang diperoleh dari 15 kali penetasan, mulai umur 0 minggu sampai 8 minggu dengan penimbangan 3 hari sekali.

Analisis kurva pertumbuhan yang digunakan adalah model Gompertz dan model Logistic. Persamaan model disajikan pada Tabel 1.

Tabel 1. Model matematis kurva pertumbuhan

\begin{tabular}{|c|c|c|c|c|}
\hline \multirow[b]{2}{*}{ Model } & \multirow[b]{2}{*}{ Persamaan } & \multicolumn{2}{|c|}{ Titik Infleksi } & \multirow{2}{*}{ Sumber Pustaka } \\
\hline & & $\mathrm{Y}_{\mathrm{i}}$ & $\mathrm{t}_{\mathrm{i}}$ & \\
\hline Gompertz & $\mathrm{Y}=\mathrm{Ae}\left(-\mathrm{Be}^{-\mathrm{kt}}\right)$ & $\mathrm{Y}_{\mathrm{i}}=\exp ^{-1} \mathrm{~A}$ & $t_{i}=(\ln B) / K$ & Kurnianto et al. (1998) \\
\hline Logistic & $\mathrm{Y}=\mathrm{A} /\left(1+\mathrm{Be}^{-\mathrm{kt}}\right)$ & $\mathrm{Y}_{\mathrm{i}}=1 / 2 \mathrm{~A}$ & $\mathrm{t}_{\mathrm{i}}=(\ln \mathrm{B}) / \mathrm{K}$ & Kurnianto et al. (1997) \\
\hline $\begin{aligned} \text { terangan : } \\
\mathrm{Y}=\text { Bobot } \mathrm{b} \\
\mathrm{A}=\text { Bobot } \mathrm{b} \\
\mathrm{e}=\text { Logaritr } \\
\mathrm{B}=\text { Paramet } \\
\mathrm{k}=\text { Laju pe } \\
\mathrm{t}=\text { Umur te } \\
\mathrm{Y}_{\mathrm{i}}=\text { Bobot } \mathrm{p} \\
\mathrm{t}_{\mathrm{i}}=\text { Umur } \mathrm{p}\end{aligned}$ & $\begin{array}{l}\text { buh saat dewasa ( } \\
\text { r }(2,7183) \\
\text { (nilai konstanta i } \\
\text { han } \\
\text { ari) } \\
\text { infleksi (gram) } \\
\text { infleksi (hari) }\end{array}$ & & & \\
\hline
\end{tabular}

\section{Parameter}

Parameter yang diamati dalam penelitian ini adalah bobot badan itik Magelang G2 mulai dari 0 minggu sampai 8 minggu yang ditimbang setiap 3 hari sekali.

\section{HASIL DAN PEMBAHASAN}

\section{Persamaan Regresi Model Pertumbuhan}

Parameter-parameter pertumbuhan pada persamaan regresi disajikan pada
Tabel 2. Nilai A dan nilai $K$ pada persamaan model saling terkait, semakin besar nilai $\mathrm{K}$, semakin cepat itik mencapai dewasa. Model Gompertz menunjukkan nilai A itik Magelang jantan dan betina masing-masing sebesar 2.386,88 g dan 1.760,02 g, sedangkan model Logistic menunjukkan nilai A itik Magelang jantan dan betina masing-masing sebesar $1.558,17 \mathrm{~g}$ dan $1.248,90 \mathrm{~g}$. 
Tabel 2. Persamaan model kurva pertumbuhan, koefisien determinasi dan Akaike Information Criterion (AIC) Itik Magelang G2

\begin{tabular}{clccc}
\hline \multirow{2}{*}{ Model } & $\begin{array}{c}\text { Jenis } \\
\text { kelamin }\end{array}$ & Persamaan & $\mathrm{R}^{2}$ & AIC \\
\hline Gompertz & Jantan & $\mathrm{Y}=2.386,88 \exp \left(-3,89 \exp ^{-0,03}\right)$ & 0,999 & 92,14 \\
& Betina & $\mathrm{Y}=1.760,02 \exp \left(-3,78 \exp ^{-0,05}\right)$ & 0,999 & 99,46 \\
\multirow{2}{*}{ Logistic } & Jantan & $\mathrm{Y}=1.558,17 /\left(1+19,78 \exp ^{-0,08}\right)$ & 0,998 & 129,22 \\
& Betina & $\mathrm{Y}=1.248,90 /\left(1+18,44 \exp ^{-0,08}\right)$ & 0,998 & 122,84 \\
\hline
\end{tabular}

Bobot dewasa itik yang dianalisis menggunakan model Gompertz sudah memenuhi standar bobot badan yang akan digunakan sebagai indukan dibandingkan dengan model Logistic. Hal ini sesuai dengan pendapat Menteri Pertanian (2012) bahwa bobot dewasa itik Magelang jantan berkisar 1,5 $\mathrm{kg}$ sampai 2,5 $\mathrm{kg}$ dan pada itik betina berisar 1,5 sampai dengan 2,0 kg. Kecepatan bobot dewasa dipengaruhi oleh seberapa besar laju pertumbuhan (K).

Nilai K pada model Logistic itik Magelang jantan dan betina masingmasing sebesar 0,08. Hasil tersebut lebih besar dari nilai K pada model Gompertz yaitu pada itik Magelang jantan dan betina masing-masing sebesar 0,03 dan 0,05. Semakin besar nilai $\mathrm{K}$ maka semakin cepat itik mencapai tingkat kedewasaan. Kurnianto et al. (1997) menyatakan bahwa laju pertumbuhan berkaitan dengan dewasa tubuh, semakin besar nilai $\mathrm{K}$ maka akan semakin cepat pencapaian bobot dewasa. Dinyatakan oleh Salman (2015) bahwa dengan parameter laju pertumbuhan model Logistic lebih tinggi dari pada model Gompertz.

\section{Analisis Model Pertumbuhan Itik Magelang Jantan dan Betina}

Hasil analisis pertumbuhan bobot badan itik Magelang jantan dan betina disajikan pada Tabel 3. Itik jantan memiliki pertumbuhan lebih cepat dari pada betina. Hal ini dipengaruhi oleh genetik dan persaingan dalam mengonsumsi pakan. Hal ini sesuai dengan pendapat Suryana et al. (2011) bahwa pertambahan bobot badan dipengaruhi oleh jenis kelamin, pakan dan faktor genetik. Bobot badan dugaan itik Magelang jantan dan betina pada model Gompertz lebih rendah dan bobot dewasa yang tinggi dibandingkan model Logistic.

Kurva pertumbuhan disajikan pada Gambar 1, 2, 3 dan 4. Dilihat dari simpangan antara bobot badan nyata dengan dugaan model Gompertz memiliki simpangan yang lebih kecil dibandingkan dengan Logistic, sehingga model Gompertz dapat digunakan dalam menseleksi dan memiliki tingkat keakuratan yang baik dalam menduga pertumbuhan itik Magelang. Hal ini sesuai dengan pendapat Rahmat (2007) bahwa semakin kecil simpangan maka semakin besar tingkat akurat pada setiap model. 
Tabel 3. Data Bobot Badan Nyata dan Dugaan Itik Magelang G2 Model Gompertz dan Logistic

\begin{tabular}{|c|c|c|c|c|c|c|c|c|c|c|c|c|}
\hline \multirow{4}{*}{ Nomor } & \multicolumn{12}{|c|}{ Jenis Kelamin } \\
\hline & \multicolumn{3}{|c|}{ Jantan } & \multicolumn{3}{|c|}{ Betina } & \multicolumn{3}{|c|}{ Jantan } & \multicolumn{3}{|c|}{ Betina } \\
\hline & $\mathrm{BN}$ & BD* & $\mathrm{S}^{*}$ & $\mathrm{BN}$ & $\mathrm{BD}^{*}$ & $\mathrm{~S}^{*}$ & $\mathrm{BN}$ & BD** & $\mathrm{S}^{* *}$ & $\mathrm{BN}$ & $\mathrm{BD} * *$ & $\mathrm{~S}^{* *}$ \\
\hline & \multicolumn{12}{|c|}{ 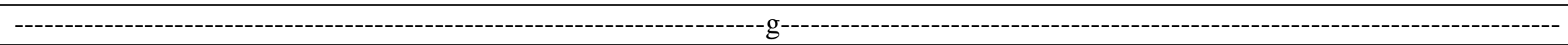 } \\
\hline 0 & 38,91 & 48,84 & 9,93 & 38,53 & 40,23 & 1,70 & 38,91 & 74,97 & 36,06 & 38,53 & 64,24 & 25,71 \\
\hline 3 & 65,22 & 69,46 & 4,24 & 62,41 & 58,81 & 3,60 & 65,22 & 93,07 & 27,85 & 62,41 & 80,47 & 18,06 \\
\hline 6 & 93,08 & 95,68 & 2,60 & 81,30 & 82,76 & 1,46 & 93,08 & 115,19 & 22,11 & 81,30 & 100,45 & 19,15 \\
\hline 9 & 123,63 & 128,04 & 4,41 & 103,07 & 112,53 & 9,46 & 123,63 & 142,06 & 18,43 & 103,07 & 124,85 & 21,78 \\
\hline 12 & 157,12 & 166,88 & 10,76 & 138,18 & 138,35 & 0,17 & 157,12 & 174,44 & 17,32 & 138,18 & 154,39 & 16,21 \\
\hline 15 & 203,48 & 212,34 & 8,86 & 184,05 & 190,21 & 6,16 & 203,48 & 213,10 & 9,62 & 184,05 & 189,74 & 5,69 \\
\hline 18 & 283,44 & 264,35 & 19,09 & 247,64 & 237,88 & 9,76 & 283,44 & 258,71 & 24,73 & 247,64 & 231,47 & 16,17 \\
\hline 21 & 320,97 & 322,65 & 1,68 & 291,45 & 290,87 & 0,58 & 320,97 & 311,83 & 9,14 & 291,45 & 279,95 & 11,50 \\
\hline 24 & 384,58 & 386,75 & 2,17 & 353,03 & 348,56 & 4,47 & 384,58 & 372,73 & 11,85 & 353,03 & 335,24 & 17,79 \\
\hline 27 & 460,51 & 456,04 & 13,47 & 412,25 & 410,16 & 2,09 & 460,51 & 441,31 & 19,20 & 412,25 & 396,98 & 15,27 \\
\hline 30 & 539,58 & 529,78 & 9,80 & 479,02 & 474,82 & 4,20 & 539,58 & 517,00 & 22,58 & 479,02 & 464,30 & 14,72 \\
\hline 33 & 619,13 & 607,15 & 11,98 & 553,89 & 541,64 & 12,25 & 619,13 & 598,72 & 20,41 & 553,89 & 535,86 & 18,03 \\
\hline 36 & 687,77 & 687,28 & 0,49 & 612,60 & 609,74 & 2,86 & 687,77 & 684,85 & 2,92 & 612,60 & 609,88 & 2,72 \\
\hline 39 & 770,59 & 769,31 & 1,28 & 683,35 & 678,29 & 5,06 & 770,59 & 773,39 & 2,80 & 683,35 & 684,31 & 0,96 \\
\hline 42 & 837,81 & 852,37 & 14,56 & 739,81 & 746,50 & 6,69 & 837,81 & 862,08 & 24,27 & 739,81 & 757,07 & 17,26 \\
\hline 45 & 926,89 & 935,68 & 8,79 & 804,16 & 813,70 & 9,54 & 926,89 & 948,64 & 21,75 & 804,16 & 826,24 & 22,08 \\
\hline 48 & $1.005,15$ & $1.018,49$ & 13,34 & 866,09 & 879,30 & 13,21 & $1.005,13$ & $1.031,02$ & 25,89 & 866,09 & 890,28 & 24,19 \\
\hline 51 & $1.086,38$ & $1.100,15$ & 13,77 & 928,87 & 942,82 & 13,95 & $1.086,38$ & $1.107,56$ & 21,18 & 928,87 & 948,16 & 19,29 \\
\hline 54 & $1.188,67$ & $1.180,08$ & 8,59 & $1.004,94$ & $1.003,86$ & 1,08 & $1.188,67$ & $1.177,09$ & 11,58 & $1.004,94$ & 999,31 & 5,63 \\
\hline 57 & $1.274,45$ & $1.257,81$ & 16,64 & $1.082,33$ & $1.062,13$ & 20,20 & $1.274,45$ & $1.238,98$ & 35,47 & $1.082,33$ & $1.043,65$ & 38,68 \\
\hline Rataan & & & 8,82 & & & 6,29 & & & 19,76 & & & 16,55 \\
\hline
\end{tabular}

Keterangan : BN : Bobot Nyata, BD : Bobot Dugaan, S : Simpangan, * : Model Gompertz, **: Model Logistic 
Gambar 1. Kuva pertumbuhan Itik Magelang jantan model Gompertz.

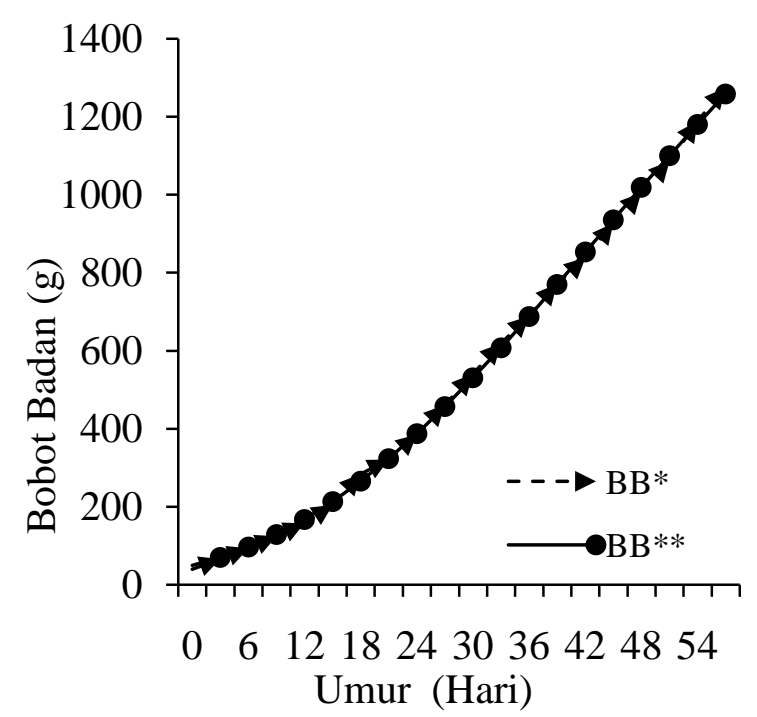

Gambar 2. Kurva pertumbuhan Itik Magelang betina model Gompertz

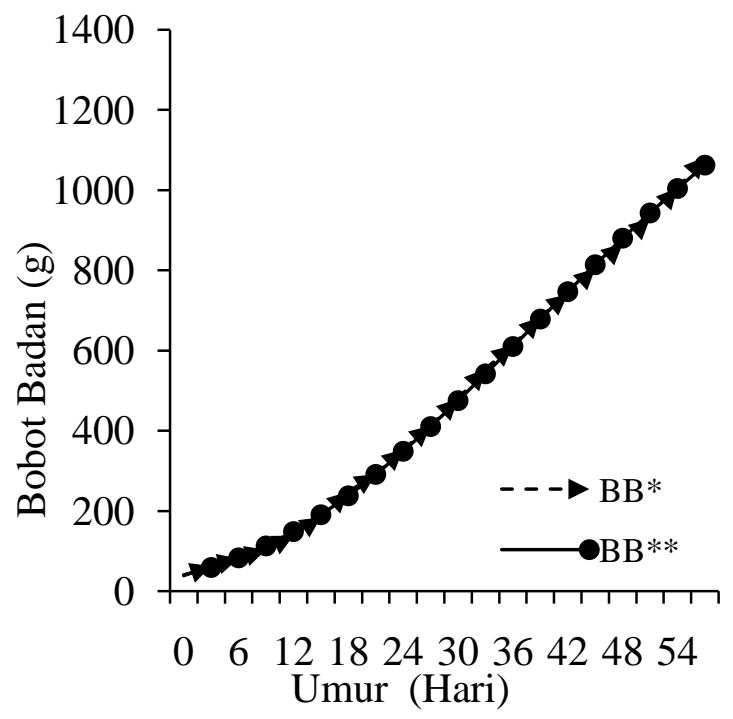

Keterangan :

BB* : Kurva Pertumbuhan Bobot Badan Nyata

BB** : Kurva Pertumbuhan Bobot Badan Dugaan Model Gompertz

Gambar 3. Kurva pertumbuhan Itik Magelang Gambar 4. Kurva pertumbuhan Itik Jantan model Logistic Magelang Betina model Logistic

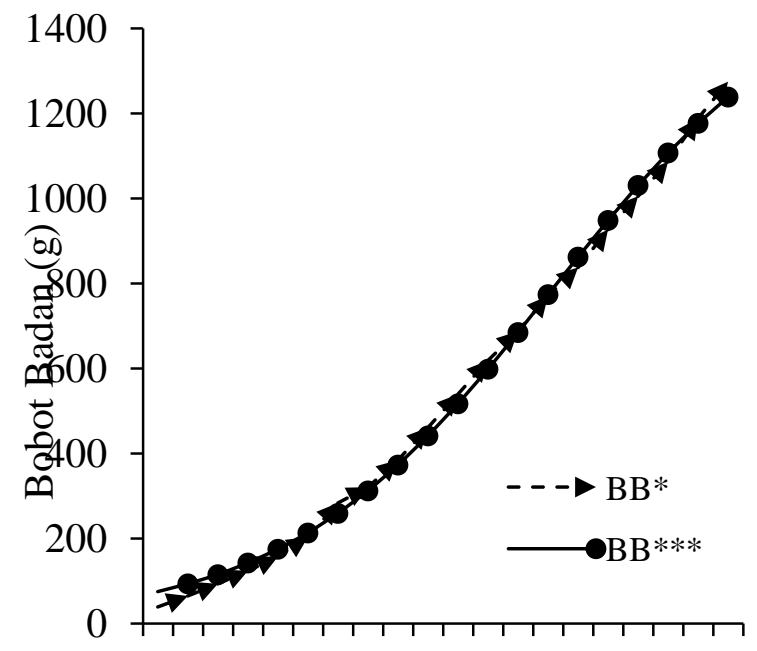

$\begin{array}{llllllllll}0 & 6 & 12 & 18 & 24 & 30 & 36 & 42 & 48 & 54\end{array}$ Umur (Hari)

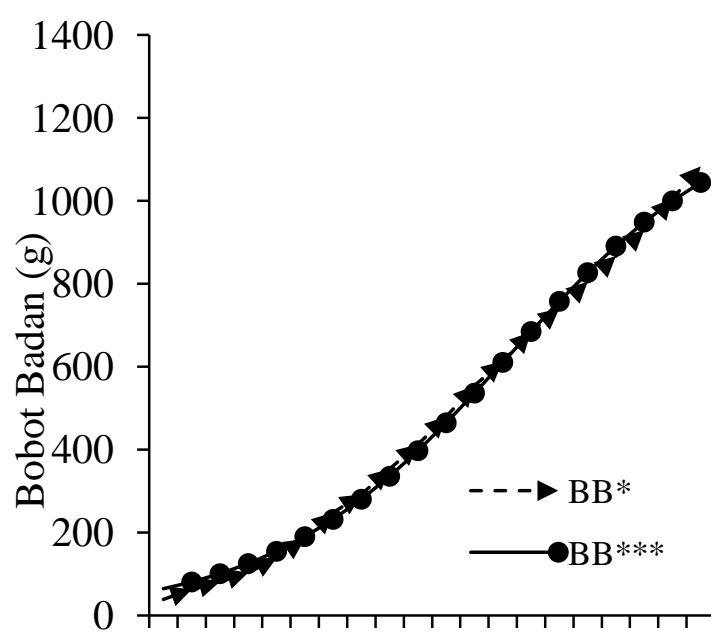

$\begin{array}{llllllllll}0 & 6 & 12 & 18 & 24 & 30 & 36 & 42 & 48 & 54\end{array}$ Umur (Hari)

Keterangan :

BB* : Kurva Pertumbuhan Bobot Badan Nyata

BB*** : Kurva Pertumbuhan Bobot Badan Dugaan Model Logistic 


\section{Titik Infleksi}

Titik infleksi merupakan titik yang menunjukkan pertambahan bobot badan mencapai maksimum. Bobot dan umur infleksi pada model Gompertz dan model Logistic disaijikan pada Tabel 4.

Tabel 4. Titik infleksi

\begin{tabular}{cccccc}
\hline Jenis & \multicolumn{2}{c}{ Gompertz } & & \multicolumn{2}{c}{ Logistic } \\
\cline { 2 - 3 } \cline { 5 - 6 } kelamin & $\mathrm{Y}_{\mathrm{i}}$ & $\mathrm{t}_{\mathrm{i}}$ & & $\mathrm{Y}_{\mathrm{i}}$ & $\mathrm{t}_{\mathrm{i}}$ \\
\hline Jantan & 878,08 & 42,93 & & 779,09 & 39,27 \\
Betina & 647,48 & 37,65 & & 624,45 & 36,43 \\
\hline
\end{tabular}

Pertumbuhan itik Magelang jantan dan betina menunjukkan bobot dan waktu infleksi yang berbeda. Titik infleksi itik Magelang jantan dicapai pada bobot 878.08 g umur 42,93 hari untuk model Gompertz, sedangkan model Logistic dicapai bobot 779.09 g pada umur 39,27 hari. Titik infleksi itik Magelang betina pada model Logistic menunjukkan bobot infleksi lebih cepat yaitu 624,45 g, umur 36,43 hari, sedangkan Gompertz 647,48 g, umur ke 37,98 hari. Menurut Arifah et al. (2013) titik infleksi itik Magelang terjadi pada umur 4-8 minggu. Hasil penelitian Arifah et al. (2013) lebih cepat dari penelitian Hardjosworo (1989) pada itik Tegal yang menunjukkan bobot infleksi itik Tegal sebesar 920,95 gram dan mengalami late growth (fase retadasi) pada mingggu ke lima.

\section{Nilai Koefisien Determinasi $\left(\mathbf{R}^{2}\right)$ dan Akaike Information Criterion (AIC)}

Hasil yang diperoleh dari model Gompertz memberikan hasil koefisien determinasi $\left(\mathrm{R}^{2}\right)$ yang baik, tetapi memberikan tingkat estimasi lebih rendah dibandingkan dengan model Logistic. Nilai $\mathrm{R}^{2}$ dan AIC disajikan pada Tabel 2. Model
Gompertz memberikan nilai $\mathrm{R}^{2}=0,999$ dibandingkan Logistic yang sebesar $\mathrm{R}^{2}=0,998$. Penilaian AIC terhadap $\mathrm{R}^{2}$ pada Gompertz jantan dan betina lebih kecil dibandingkan Logistic (Tabel 2). Makin kecil nilai AIC maka semakin baik perhitungan dalam pendugaan sebuah model pertumbuhan dan $\mathrm{R}^{2}$ semakin mendekati angka 1. Penelitian Kurnianto et al. (1997) pada pertumbuhan mencit yang menggunakan model Gompertz dan model Logistic, nilai $\mathrm{R}^{2}$ paling tinggi 0,999 , yang artinya kedua model menghasilkan dugaan bobot badan yang akurat. Raji et al. (2015) menambahkan bahwa semakin kecil nilai AIC maka model tersebut semakin baik dalam menganalisis pertumbuhan.

\section{KESIMPULAN}

Kesimpulan penelitian ini adalah kedua model memiliki tingkat akurasi yang tinggi, Model Gompertz memiliki tingkat akurasi yang lebih tinggi dibandingkan dengan Logistic.

\section{DAFTAR PUSTAKA}

Arifah, N., Ismoyowati dan N. Iriyanti. 2013. Tingkat pertumbuhan dan. 
konversi pakan pada berbagai itik Lokal jantan (Anas plathyrhinchos) dan itik Manila jantan (Cairrina moschata). Jurnal Ilmiah Peternakan. 1(2): 718-725.

Brahmantiyo, B. dan Y.C. Raharjo. 2011. Peningkatan Produktivitas Kelinci Rex, Satin dan Persilangannya melalui Seleksi. JITV 16 (4): 243252

Hardjosworo, P. S. $1989 . \quad$ Respon Biologik Itik Tegal terhadap Pakan Pertumbuhan dengan Berbagai Kadar Protein. Program Pasca Sarjana. Institut Pertanian Bogor, Bogor. (Desertasi).

Inounu, I., D. Mauluddin, R. R. Noor dan Subandriyo. 2007. Analisis kurva pertumbuhan domba garut dan persilangannya. JITV. 12(4): 286299.

Kurnianto, E., A. Shinjo dan D. Suga. 1997. Comparison of the three growth curve models for describing the growth patterns in wild and laboratory mice. J. Vet. Epidemiol. 1(2):49-55.

Kurnianto, E., A. Shinjo dan D. Suga. 1998. Analysis of growth in intersubspecific crossing of mice using Gompertz model. AsianAustralasian Journal Animal Sciances. 11(1): 84-88.

Mahfudz. L.D, S. Kismiati dan T.A. Sarjana. 2005. Fenotipik dari Itik
Magelang yang produktif (Phenotipic of High Productivity of Magelang Ducks). Fakultas Peternakan Universitas Diponegoro, Semarang. Seminar Nasional 13 September 2005. Hal 779-785.

Mesrawati, L. 2001. Studi tentang penambahan probiotik terhadap penampilan ayam Kedu yang mendapat ransum berbeda level protein dan serat kasar. Program Studi Magister Ilmu Ternak Universitas Diponegoro, Semarang. (Tesis)

Menteri Pertanian. 2013. Penetapan Rumpun Itik Magelang. Nomor 701/Kpts/PD.410.

Prasetyo, L. H. dan T. Susanti. 2007. Pendugaan parameter genetik bobot hidup Itik Alabio dan Mojosari pada periode starter. JITV 12(3) : 212-217.

Rahmat, D. 2007. Model kurva pertumbuhan itik tegal jantan sampai umur delapan minggu.J. Ilmu Ternak. 7(1):12- 15.

Raji. A. O., S. T. Mbap and J. Aliyu. 2014. Comparison of different models to describe growth of the Japanese quail (Coturnix japonica). Trakia Journal of Sciences, 12 (2):182188.

Salman, L. B., C. Sumantri, R. R. Noor, A. Saefuddin dan C. Talib. 2015. Kurva pertumbuhan sapi Friesian. 
Holstein dari lahir sampai siap kawin berdasarkan tingkat kelahiran. J. Veteriner. 16 (1): 96106.

Supariyanto, A., Subandriyo, Wiradarya dan H. Martojo. 2001. Analisis kurva pertumbuhan non linier domba lokal Sumatra dan persilanganya. JITV. 6 (4): 259264

Suryana, R. R. Noor, P. S. Hardjosworo dan L. H. Prasetyo. 2011.
Karakteristik Fenotipe Itik Alabio (Anas platyrhynchos Borneo) di Kalimantan Selatan. Balai Pengkajian Teknologi Pertanian, Bajarbaru. Buletin Plasma Nutfah. 17(1): 61-67.

Yuniwarti, E. Y. W dan H. Muliani. 2014. Status heterofil, limfosit dan rasio H/L berbagai itik lokal di Provinsi Jawa Tengah, J. Ilmu Ternak. 1(5): 22-27. 